\title{
EFEKTIVITAS PENDEKATAN PEMBELAJARAN MATEMATIKA REALISTIK TERHADAP KEMAMPUAN PENALARAN MATEMATIS SISWA KELAS VIII SMP NEGERI 10 KENDARI
}

\author{
Hendrik $^{1)}$, Hasnawati ${ }^{2)}$, Saleh $^{3)}$ \\ 1,2,3 Jurusan Pendidikan Matematika FKIP Universitas Halu Oleo \\ Email: hendrikbintanglaut@gmail.com ${ }^{1)}$, hasnawati@ uho.ac.id ${ }^{2)}$, saleh0377@gmail.com ${ }^{3)}$
}

\begin{abstract}
Abstrak
Penelitian ini bertujuan untuk: Mengetahui efektivitas pendekatan pembelajaran matematika realistik terhadap kemampuan penalaran matematis siswa kelas VIII SMP Negeri 10 Kendari. Populasi dalam penelitian ini adalah seluruh siswa kelas VIII SMP Negeri 10 Kendari yang terdiri dari 6 kelas paralel yaitu $\mathrm{VIII}_{1}-\mathrm{VIII}_{6}$. Teknik pengambilan sampel menggunakan teknik Simple Random Sampling. Penentuan kelas eksperimen dilakukan secara random dan diperoleh kelas VIII $_{1}$ sebagai kelas eksperimen dan kelas VIII $_{5}$ sebagai kelas kontrol. Teknik pengumpulan data dilakukan dengan pemberian instrumen penelitian berupa lembar observasi, angket respon siswa dan tes kemampuan penalaran matematis siswa berbentuk tes uraian. Teknik analisis data menggunakan statistik deskriptif dan statistik inferensial. Berdasarkan hasil penelitian diperoleh bahwa pendekatan pembelajaran Matematika Realistik efektif terhadap kemampuan penalaran matematis siswa kelas VIII SMP Negeri 10 Kendari. Uji hipotesis menunjukkan pendekatan pembelajaran matematika realistik secara signifikan lebih efektif terhadap kemampuan penalaran matematis siswa kelas VIII SMP Negeri 10 Kendari dibandingkan pendekatan saintifik.
\end{abstract}

Kata Kunci: pendekatan pembelajaran, matematika realistik, kemampuan penalaran

\section{THE EFFECTIVENESS OF REALISTIC MATHEMATICS EDUCATION APPROACH ON STUDENT'S MATHEMATICAL REASONING ABILITY CLASS VIII SMP NEGERI 10 KENDARI}

\begin{abstract}
This study aims to: Determine the effectiveness of the realistic mathematics education approach on the student's mathematical reasoning abilities of the class VIII SMP Negeri 10 Kendari. The population in this study were all students of class VIII SMP Negeri 10 Kendari which consisted of 6 parallel classes, namely $\mathrm{VIII}_{1}$ - VIII ${ }_{6}$. The sampling technique used the simple random sampling technique. The determination of the experimental class was carried out randomly and obtained class $V I I I_{1}$ as the experimental class and class VIII $I_{5}$ as the control class. The data collection technique was carried out by providing research instruments in the form of observation sheets, student response questionnaires and tests of students' mathematical reasoning abilities in the form of essay tests. The data analysis technique used descriptive statistics and inferential statistics. Based on the results of the study, it was found that the realistic mathematics education approach was effective on the students mathematical reasoning abilities of the class VIII SMP Negeri 10 Kendari. Hypothesis testing shows that the realistic mathematics education approach is significantly more effective for the eighth grade students' mathematical reasoning abilities of SMP Negeri 10 Kendari compared to the scientific approach.
\end{abstract}

Keyword: realistik matematics education approach, student's matematical reasoning ability 


\section{Pendahuluan}

Pendidikan adalah usaha sadar dan terencana untuk mewujudkan suasana belajar dan proses pembelajaran agar peserta didik secara aktif mengembangkan dirinya untuk memiliki kekuatan spiritual keagamaan, pengendalian diri, kepribadian, kecerdasan, akhlak mulia, serta keterampilan yang diperlukan dirinya, masyarakat, bangsa dan negara.

Sejak lahir seseorang sudah mulai di didik oleh orang tuanya. Pendidikan ini sering disebut sebagai pendidikan informal. Orang tua biasanya mengajarkan kepada anaknya untuk dapat berbicara, makan dengan menggunakan tangan kanan, cara berpakaian, dan lain-lain. Memasuki usia lima tahun, biasanya anak sudah didaftarkan di sekolah dan terjadilah apa yang disebut dengan pendidikan formal. Selain itu, ada juga pendidikan non formal seperti bimbingan belajar, pelatihan dan lain sebagainya. Hal terpenting dalam pendidikan adalah bagaimana cara agar peserta didik dapat belajar dengan baik sehingga terjadi perubahan tingkah laku dalam dirinya menjadi lebih baik.

Matematika adalah ilmu universal yang mendasari perkembangan teknologi modern, mempunyai peranan penting dalam berbagai disiplin ilmu dan memajukan daya pikir manusia. Tujuan pembelajaran matematika adalah untuk mempersiapkan siswa dalam menghadapi tantangan masa depan melalui latihan bertindak atas dasar pemikiran logis, rasional, kritis, cermat, jujur, efisien dan efektif serta siswa diharapkan dapat menggunakan matematika dalam kehidupan sehari-hari dan dalam mempelajari berbagai ilmu pengetahuan yang penekanannya pada penataan nalar dan pembentukan sikap siswa serta keterampilan dalam penerapan matematika.

National Council of Teacher of Mathematics (NTCM) dalam Dhamayanti (2000: 2) menyatakan bahwa terdapat kemampuan yang sebaiknya dimiliki siswa antara lain kemampuan pemecahan masalah (problem solving), kemampuan penalaran (reasoning and proof), kemampuan menghubungkan (connections), kemampuan komunikasi (comunications), dan kemampuan representasi (representation).

Hidayat (2014: 18) menyatakan kemampuan penalaran matematis adalah kemampuan siswa dalam memperkirakan jawaban dan proses solusi dari masalah yang diberikan. Kemampuan memperkirakan jawaban ini sangat diperlukan dalam pengerjaan soal-soal matematis untuk mempermudah dalam menganalisis setiap masalah yang muncul.

Kadir dalam Marlina (2010: 310) menyatakan untuk meningkatkan kemampuan penalaran banyak faktor yang harus diperhatikan seperti metode yang diterapkan guru, sarana dan prasarana, motivasi belajar matematika, dan sikap positif terhadap matematika. Namun, ketepatan dalam memilih suatu pendekatan akan menjadi pedoman atau orientasi dalam pemilihan komponen pembelajaran lainnya terutama strategi dan metode pembelajaran. Lebih lanjut, Gravemeijer dalam Sembiring (2010: 13) menyatakan guru harus mampu dalam menciptakan budaya kelas yang berorientasi pada permasalahan dan mengajak siswa dalam pelajaran yang bersifat interaktif, serta guru harus mampu merancang kegiatan pembelajaran yang dapat mendorong penemuan kembali matematika.

Hasil penelitian yang dikemukakan oleh Murniati dalam Sermatan (2018: 56) bahwa kemampuan penalaran aljabar masih tergolong rendah. Para siswa masih kesulitan dalam melakukan operasi tambah, kurang, kali dan bagi bentuk aljabar terutama yang menggunakan bilangan bulat dan suku banyak. Hal ini sejalan dengan hasil tes kemampuan penalaran siswa kelas VIII SMP Negeri 10 Kendari yang dipilah dari hasil ulangan harian siswa yang menunjukkan bahwa kemampuan penalaran matematis siswa kelas VIII SMP Negeri 10 Kendari tergolong rendah. Berdasarkan hasil observasi awal yang dilakukan oleh peneliti pada hari Jum'at tanggal 6 September 2019 di SMP Negeri 10 Kendari diperoleh informasi bahwa pembelajaran matematikanya masih didominasi oleh penggunaan pendekatan pembelajaran yang kegiatannya masih berpusat pada guru. Aktivitas siswa dapat dikatakan hanya mendengarkan penjelasan guru dan mencatat hal-hal yang dianggap penting. Guru menjelaskan bahwa selama pembelajaran berlangsung, siswa yang diajarinya ribut dan tidak fokus dalam menerima pelajaran. Adapun kemampuan penalaran siswa masih tergolong rendah, hal ini disebabkan siswa belum mampu dalam menemukan pola bilangan, siswa masih melakukan kesalahan manipulasi matematik, siswa belum mampu mengungkapkan 
pernyataan bernilai salah, siswa belum membuktikan kesejajaran garis, serta siswa masih melakukan kesalahan dalam menggambar grafik persamaan garis lurus.

Menurut Fauzan dalam Sembiring (2010: 112), salah satu permasalahan terbesar dalam pembelajaran matematika ialah menyajikan matematika sebagai produk jadi, siap pakai, abstrak dan diajarkan secara mekanistik dalam hal ini guru mendiktekan rumus dan prosedur ke siswa. Lebih lanjut Fauzan mengamati bahwa siswa menggunakan prosedur tanpa memahaminya. Hal ini mengindikasi bahwa pelajaran selama ini belum bermakna sehingga belum menimbulkan pemahaman materi yang dipelajari. Belajar matematika disebut bermakna apabila siswa mengalami sendiri apa yang dipelajari, daripada hanya mengetahui secara lisan saja. Kebermaknaan belajar matematika dipengaruhi oleh cara guru menyampaikan matematika itu sendiri.

Masalah tersebut perlu kiranya dicarikan solusi. Sanjaya dalam Ito (2014: 74) menyatakan guru harus memiliki kemampuan dalam mengaplikasikan berbagai metodologi dan strategi pembelajaran. Berkaitan dengan itu, upaya yang bisa dilakukan adalah bagaimana seorang guru memimpin pembelajaran yang berpusat pada siswa, sehingga siswa menjadi aktif, kreatif, dan saling berkomunikasi tentang materi yang dipelajarinya. Alangkah baiknya jika materi pembelajaran dikaitkan dengan masalah keseharian siswa sehingga timbul adanya kebutuhan untuk mempelajari matematika, sehingga proses yang terjadi adalah siswa dapat secara aktif dalam menemukan konsep matematika. Alternatif untuk menciptakan suasana pembelajaran tersebut adalah dengan menggunakan pendekatan Pembelajaran Matematika Realistik (PMR). Pembelajaran dalam PMR tidak dimulai dari definisi, teorema atau sifat-sifat yang kemudian dilanjutkan dengan contoh-contoh, seperti yang selama ini dilaksanakan diberbagai sekolah. Namun, sifat-sifat, definisi, cara, prinsip, dan teorema diharapkan seolah-olah ditemukan kembali oleh siswa melalui masalah konstektual yang diberikan guru diawal pembelajaran sehingga siswa diharapkan dapat mengkontruksi atau membangun sendiri pengetahuan yang akan diperolehnya. Oleh karena itu, konsep PMR sejalan dengan kebutuhan untuk memperbaiki pendidikan matematika di Indonesia.
Berdasarkan uraian latar belakang, maka rumusan masalah dalam penelitian ini adalah (1) bagaimana deskripsi aktivitas siswa yang diajar dengan pendekatan PMR dan yang diajar dengan pendekatan saintifik?, (2) bagaimana deskripsi kemampuan guru dalam mengelola pembelajaran dengan pendekatan PMR?, (3) apa respon siswa terhadap pembelajaran dengan pendekatan PMR?, (4) bagaimana kemampuan penalaran matematis siswa kelas VIII SMP Negeri 10 Kendari yang diajar dengan pendekatan PMR?, (5) bagaimana kemampuan penalaran matematis siswa kelas VIII SMP Negeri 10 Kendari yang diajar dengan pendekatan saintifik?, (6) Apakah pendekatan PMR efektif terhadap kemampuan penalaran matematis siswa kelas VIII SMP Negeri 10 Kendari?, (7) Apakah pendekatan PMR lebih efektif terhadap kemampuan penalaran matematis siswa kelas VIII SMP Negeri 10 Kendari jika dibandingkan dengan pendekatan saintifik?

Efektivitas berasal dari kata efektif. Menurut Kamus Besar Bahasa Indonesia, kata efektif mempunyai arti efek, pengaruh, akibat, atau dapat membawa hasil. Menurut Sutikno dalam Megantara (2017: 8) efektivitas pembelajaran berarti kemampuan dalam melaksanakan pembelajaran yang telah direncanakan yang memungkinkan siswa untuk dapat belajar dengan mudah dan dapat mencapai tujuan yang telah diharapkan. Sementara Sinambela (2008: 78) menyatakan pembelajaran dikatakan efektif apabila mencapai sasaran yang diinginkan, baik dari segi tujuan pembelajaran maupun dari prestasi siswa yang maksimal.

Menurut Mulyasa dalam Tripuasarina (2015: 24) bahwa efektivitas berkaitan dengan terlaksananya tugas pokok, tercapainya tujuan, ketepatan waktu, dan adanya partisipasi aktif dari anggota. Sedangkan menurut Sinambela (2008: 74), pembelajaran dikatakan efektif apabila siswa secara aktif terlibat dalam pengorganisasian dan penemuan informasi (pengetahuan) serta keterkaitan informasi yang diberikan. Siswa tidak hanya secara pasif menerima pengetahuan yang diberikan guru. Selanjutnya Diamond dalam Puspa (2014: 98) berpendapat keefektifan juga dapat diukur dengan melihat minat siswa terhadap kegiatan pembelajaran. Minat siswa tersebut akan mempengaruhi aktivitas siswa selama proses belajar mengajar. Menurut Uno dalam Tripuasarina (2015: 25) pembelajaran yang 
efektif terdapat dua hal penting, yaitu terjadinya belajar pada peserta didik dan apa yang dilakukan oleh guru untuk membelajarkan peserta didiknya. Suatu proses belajar-mengajar dapat dikatakan berhasil dengan baik, jika kegiatan belajar-mengajar dapat membangkitkan proses belajar.

Berdasarkan pengertian dari para ahli tersebut, dapat disimpulkan bahwa efektivitas adalah ukuran kemampuan untuk melaksanakan pembelajaran yang telah direncanakan yang memungkinkan siswa untuk belajar sehingga tercapai tujuan pembelajaran yang diharapkan. Efektivitas pada dasarnya menunjukkan pada taraf tercapainya hasil belajar.

Sejak tahun 1971, Institute Freudenthal mengembangkan suatu pendekatan teoritis terhadap pembelajaran matematika yang dikenal dengan RME (Realistik Mathematics Education). RME menggabungkan pandangan tentang apa itu matematika, bagaimana peserta didik belajar matematika dan bagaimana matematika diajarkan. Freudenthal berkeyakinan bahwa peserta didik tidak boleh dipandang sebagai passive receivers of ready made mathematics (penerima pasif matematika yang sudah jadi). Menurutnya, pendidikan harus mengarahkan peserta didik pada penggunaan berbagai situasi dan kesempatan untuk menemukan kembali matematika dengan cara mereka sendiri.

Hadi (2017: 24) menyatakan dunia nyata dalam PMR digunakan sebagai titik awal sebagai pengembangan ide dan konsep matematika. Dunia nyata adalah segala sesuatu diluar matematika. Berdasarkan pemikiran Hans Freudenthal, dalam PMR matematika dianggap sebagai aktivitas insani (Human Activity) dan harus dikaitkan dengan realitas. Menurut filsafat PMR, siswa harus diberi kesempatan untuk merekacipta kembali (to reinvent) matematika dibawah bimbingan orang dewasa (Gravemeijer dalam Hadi, 2017: 10) dan rekacipta ide dan konsep matematika tersebut harus dimulai dari penjelajahan berbagai persoalan dan situasi 'dunia nyata' (De Lange dalam Hadi, 2017: 10).

Gravemeijer dalam Marlina (2014: 207), terdapat tiga prinsip utama dalam pendekatan pembelajaran matematika realistik yaitu: 1) guided reinvention and progressive mathematization (penemuan terbimbing dan bermatematika secara progressif 2) Didaktical phenomenology (fenomena pembelajaran), dan
3) self developed models (pengembngan model mandiri).

Karakteristik dari pendekatan pembelajaran matematika realistik merupakan penjabaran dari ketiga prinsip utama tersebut, yaitu 1) the use of contex (menggunakan masalah kontekstual), 2) the use models (menggunakan berbagai model), 3) student contribution (kontribusi siswa), 4) interactivity (interaktivitas) dan 5) intertwining (terintegrasi) (Marlina, 2014). Penjelasan secara singkat dari kelima karakteristik tersebut adalah sebagai berikut.

1) Menggunakan masalah kontekstual

Pembelajaran matematika diawali dengan masalah kontekstual, sehingga memungkinkan siswa menggunakan pengalaman atau pengetahuan yang telah dimiliki sebelumnya secara langsung. Masalah kontekstual tidak hanya berfungsi sebagai sumber pematematikaan, tetapi juga sebagai sumber untuk mengaplikasikan kembali matematika.

2) Menggunakan berbagai model

Istilah berkaitan dengan model matematika yang dibangun sendiri oleh siswa dalam mengaktualisasikan masalah kontekstual kedalam bahasa matematika, yang merupakan jembatan bagi siswa untuk membuat sendiri model-model dari situasi nyata ke abstrak atau dari situasi informal ke formal.

3) Kontribusi Siswa

Siswa diberi kesempatan seluas-luasnya untuk mengembangkan berbagai strategi informal yang dapat mengarahkan pada pekonstruksian berbagai prosedur untuk memecahkan masalah. Dengan kata lain, kontribusi yang besar dalam proses pembelajaran diharapkan datang dari siswa dan bukan dari guru. Artinya semua pikiran dan pendapat siswa sangat diperhatikan dan dihargai.

4) Interaktif

Interaksi antara siswa dan guru, siswa dengan siswa, serta siswa dengan perangkat pembelajaran merupakan hal yang sangat penting dalam PMR. Bentuk-bentuk interaksi seperti: negosiasi, penjelasan, pembenaran, persetujuan, pertanyaan atau refleksi digunakan untuk mencapai bentuk bentuk pengetahuan matematika formal dari bentuk pengetahuan matematika informal yang ditemukan sendiri oleh siswa. 


\section{5) Keterkaitan}

Proses pembelajaran dengan RME menggunakan masalah kontekstual (contextual problems) sebagai titik awal dalam pembelajaran matematika. Dalam hal ini siswa melakukan aktivitas matematisasi horizontal, yaitu pemodelan situasi masalah dengan menggunakan bahasa matematika yang sudah dia miliki, atau dengan kata lain matematisasi horizontal bergerak dari dunia nyata ke dunia simbol. Kemudian tiba pada matematisasi vertikal yaitu membangun dan mengembangkan pengetahuan dan keterampilan dalam dunia simbol sehingga memperkuat konsep materi yang dipelajari.

$$
\text { Langkah-langkah }
$$

pendekatan

pembelajaran matematika realistik yang dikemukakan Saleh (2008: 103) kegiatan inti dalam pembelajaran matematika realistik, 1) memahami masalah kontekstual, 2) menyelesaikan masalah kontekstual, 3) membandingkan atau mendiskusikan jawaban dan 4) menyimpulkan. Berikut penjelasan singkatnya:

\section{1) Memahami masalah kontekstual}

Guru memberikan masalah kontekstual dan meminta siswa untuk memahami masalah tersebut. Jika ada bagian-bagian tertentu yang kurang atau belum dipahami siswa, maka siswa yang memahami bagian itu diminta untuk menjelaskannya kepada temannya yang belum paham. Jika siswa tadi yang belum paham tidak puas, guru menjelaskan lebih lanjut dengan cara memberi petunjuk-petunjuk atau saran-saran terbatas yang menuntun siswa untuk memahami masalah (soal), seperti: "apa yang diketahui dari soal tu?", "apa yang ditanyakan?", "bagaimana strategi atau cara atau prosedur yang akan digunakan untuk menyelesaikan soal itu?". Pada tahap ini, karakteristik yang muncul adalah menggunakan masalah kontekstual dan interaksi.

2) Meyelesaikan masalah kontekstual

Siswa mendeskripsikan masalah kontekstual, melakukan interpretasi aspek matematika yang ada pada masalah yang dimaksud dan memikirkan strategi pemecahan masalah. Siswa secara individual diminta menyelesaikan masalah kontekstual pada buku siswa atau LKPD dengan cara mereka sendiri. Cara pemecahan masalah yang berbeda lebih diutamakan. Guru memotivasi siswa untuk menyelesaikan masalah tersebut dengan memberikan pertanyaan-pertanyaan penuntun agar siswa dapat menyelesaikan masalah tersebut. "bagaimana kamu tahu itu?", "bagaimana caranya?", "mengapa kamu berpikir seperti itu?" dan lain-lain. Pada tahap ini siswa dibimbing untuk menemukan kembali konsep atau prinsip matematika melalui masalah kontekstual yang diberikan. Selain itu, siswa juga diarahkan untuk membentuk dan menggunakan model sendiri guna memudahkan menyelesaikan masalah (soal) kontekstual. Guru diharapkan tidak perlu memberi tahu penyelesaian soal atau masalah tersebut, sebelum siswa memperoleh penyelesaian sendiri. Pada langkah ini, karakteristik PMR yang muncul adalah menggunakan model dan interaksi.

3) Membandingkan atau mendiskusikan jawaban

Guru membentuk kelompok dan meminta kelompok tersebut untuk bekerja sama mendiskusikan penyelesaian masalah-masalah yang telah diselesaikan secara individu (negosiasi, membandingkan dan diskusi). Siswa dilatih untuk mengeluarkan ide-ide yang mereka miliki.

Setelah diskusi dilakukan, guru menunjuk wakil-wakil kelompok untuk menuliskan masing-masing ide penyelesaian dan alasan dari jawabannya, kemudian guru sebagai fasilitator dan moderator mengarahkan siswa berdiskusi. Tahap ini dapat digunakan untuk melatih keberanian siswa mengemukakan pendapat, meskipun berbeda dengan teman lain atau bahkan dengan gurunya. Karakteristik PMR yang muncul pada tahap ini adalah penggunaan ide atau kontribusi siswa dan interaksi antara siswa dengan siswa, antara guru dengan siswa dan antara siswa dengan sumber belajar.

4) Menyimpulkan

Dari hasil diskusi kelas, guru mengarahkan siswa untuk menarik kesimpulan tentang konsep atau definisi, teorema, prinsip atau prosedur matematika yang terkait dengan masalah kontekstual yang baru diselesaikan. Karakteristik PMR yang muncul pada langkah ini adalah adanya interaksi antar siswa dengan guru dan kontribusi siswa.

Menurut KBBI, penalaran adalah cara menggunakan nalar, hal mengendalikan sesuatu dengan nalar dan bukan dengan perasaan atau pengalaman, atau proses mental dalam mengembangkan pikiran dari beberapa fakta atau prinsip. Menurut Sumarmo dalam Permana (2007: 116), penalaran merupakan proses 
berpikir dalam proses penarikan kesimpulan. Hidayat (2014: 18), Kemampuan penalaran matematis adalah kemampuan siswa dalam memperkirakan jawaban dan proses solusi dari masalah yang diberikan. Kemampuan memperkirakan jawaban ini sangat diperlukan dalam pengerjaan soal-soal matematis untuk mempermudah dalam menganalisis soal yang akan diselesaikan. NCTM (2000) kemampuan penalaran adalah kemampuan mengemukakan alasan dalam mengontruksi dan memeriksa suatu pernyataan matematika serta mengembangkan dalam mengapresiasi pembuktian dalam matematika. Suharta dalam Octriana (2019: 131), penalaran merupakan suatu alat untuk mengkontruksi suatu pengetahuan. Berdasarkan beberapa pernyataan dari para ahli tersebut dapat disimpulkan bahwa kemampuan penalaran matematis adalah kemampuan mengemukakan alasan secara logis dalam mengontruksi suatu pengetahuan.

Secara umum, Penalaran dikelompokkan menjadi dua bagian besar, yaitu penalaran induktif dan penalaran deduktif. Penalaran induktif merupakan cara yang digunakan untuk menemukan suatu pola atau kesimpulan umum melalui identifikasi kasuskasus yang digunakan untuk menemukan suatu pola atau kesimpulan umum melalui identifikasi kasus-kasus yang spesifik. Untuk menggeneralisasi kasus-kasus yang terjadi, perlu dilakukan pengamatan untuk menemukan pola dan keteraturannya. Penalaran induktif dalam matematika sering dijumpai pada berbagai materi, salah satunya terdapat di materi geometri pada penentuan karakteristik bangun datar.

Ciri-ciri penalaran adalah 1) Adanya suatu pola pikir yang disebut logika. Hal ini dapat dikatakan bahwa kegiatan penalaran merupakan proses berpikir logis. Berpikir logis ini diartikan sebagai berpikir menurut suatu pola tertentu atau menurut logika tertentu, 2). Proses berpikirnya bersifat analitis penalaran merupakan suatu kegiatan yang mengandalkan diri pada suatu analitis, dalam kerangka berpikir yang dipergunakan untuk analitis tersebut adalah logika penalaran yang bersangkutan.
Indikator kemampuan penalaran matematis yang digunakan dalam penelitian ini adalah mengadopsi indikator yang dikemukakan oleh Wulandari (2011: 14) adalah sebagai berikut.

1) Kemampuan menyajikan pernyataan matematika secara lisan, tertulis, gambar, atau diagram

2) Kemampuan mengajukan dugaan

3) Melakukan manipulasi matematik

4) Kemampuan menyusun bukti, memberikan alasan terhadap suatu solusi

5) Kemampuan menarik kesimpulan dari pernyataan

6) Kemampuan memeriksa keshahihan suatu argumen

7) kemampuan menemukan pola atau sifat dari gejala matematis untuk membuat generalisasi

\section{Metode}

Penelitian eksperimen ini dilaksanakan di SMP Negeri 10 Kendari. Waktu pelaksanaannya dilakukan pada semester genap tahun ajaran 2019/2020. Sampel dalam penelitian ini terbagi dalam dua kelas, yaitu terdiri atas kelas eksperimen yang diajar dengan pendekatan pembelajaran matematika realistik (PMR) dan kelas kontrol yang diajar dengan pendekatan pembelajaran saintifik. Pengambilan sampel dalam penelitian ini dilakukan dengan teknik Simple Random Sampling. Teknik pengambilan sampel ini dilakukan secara acak tanpa memperhatikan strata yang ada dalam populasi itu yang didasari dengan asumsi bahwa penempatan siswa dalam kelas-kelas secara random, tidak ada kelas khusus dengan pertimbangan dua kelas yang diambil dapat mewakili karakter seluruh kelas parallel, dimana kedua kelas yang diambil memiliki kemampuan yang setara. Kedua kelas tersebut yang akan dijadikan kelas penelitian dan untuk penentuan kelas eksperimen dan kelas kontrol dilakukan secara acak (random), sehingga diperoleh kelas $\mathrm{VIII}_{1}$ sebagai kelas eksperimen dan kelas $\mathrm{VIII}_{5}$ sebagai kelas kontrol. Dengan desain sebagai berikut: 
Tabel 1

Desain Penelitian

\begin{tabular}{ccc}
\hline Kelas & Perlakuan & Post-Test \\
\hline Eksperimen & $\mathrm{X}$ & $\mathrm{O}_{1}$ \\
Kontrol & - & $\mathrm{O}_{2}$ \\
\hline
\end{tabular}

Keterengan:

$\mathrm{O}_{1}=$ tes kemampuan penalaran matematis siswa kelas eksperimen

$\mathrm{X}=$ perlakuan baru dengan menerapkan pendekatan PMR

$\mathrm{O}_{2}=$ tes kemampuan penalaran matematis siswa kelas control

- $\quad=$ perlakuan biasa dengan menerapkan pendekatan saintifik

Pengumpulan data dalam penelitian ini dilakukan melalui lembar observasi dan tes kemampuan penalaran matematis siswa dalam bentuk soal essay kepada siswa. Data yang diperoleh dalam penelitian ini akan dianalisis

(Sugiyono, 2008: 112)

dengan menggunakan dua statistik, yaitu, statistik deskriptif dan statistik inferensial. (1) Analisis deskriptif dimaksudkan untuk mendeskripsikan kemampuan penalaran matematis siswa, (2) Analisis inferensial dimaksudkan untuk menguji hipotesis efektivitas pendekatan pembelajaran matematika realistik dan pendekatan saintifik terhadap kemampuan penalaran matematis siswa.

$$
\text { Nilai }=\frac{\text { skor } \text { yang diperoleh }}{\text { skor total }} \times 100
$$

Nilai yang diperoleh siswa inilah yang akan dijadikan data dalam penelitian ini. Berikut kriteria interpretasi skor siswa.

\section{Tabel 2}

Kriteria Interpretasi Skor Siswa

\begin{tabular}{cc}
\hline Rentang Nilai & Kategori \\
\hline $80<X \leq 100$ & Sangat Baik \\
$60<X \leq 80$ & Baik \\
$40<X \leq 60$ & Cukup \\
$20<X \leq 40$ & Kurang \\
$0<X \leq 20$ & Sangat Kurang \\
\hline
\end{tabular}

Pembelajaran juga dikatakan efektif jika rata-rata skor siswa dinilai beradapada kategori "baik" atau "sangat baik". Skor siswa yang tidak memenuhi kriteria keefektifan akan dijadikan bahan pertimbangan untuk merevisi perangkat pembelajaran selanjutnya.

\section{Hasil}

Berdasarkan hasil observasi kemampuan guru dalam mengelola pembelajaran dengan menggunakan pendekatan matematika realistik dikelas eksperimen pada materi bangun ruang sisi datar terkategori baik dan sangat baik. Tingkat keberhasilan secara berturut-turut $75 \%$; 87,50\%; 87,50\%; 93,75\%; dan 93,75\%.

Berdasarkan hasil observasi aktivitas siswa dikelas eksperimen ketercapaian aspek yang diamati mencapai 70,83\% dengan kategori kurang aktif. Selanjutnya pada pertemuan kedua hingga pertemuan kelima terkategori aktif dengan persentase berturut-turut $79,17 \%$; $83,33 \% ; 83,33 \%$ dan $81,25 \%$. Sedangkan pada kelas kontrol dengan menerapkan pendekatan saintifik ketercapaian aspek yang diamati berturut-turut $68,75 \% ; 72,92 \% ; 81,25 \% ; 83,33 \%$ dan 81,25 dengan kategori kurang aktif pada pertemuan pertama dan pertemuan kedua sedang pada pertemuan selanjutnya terkategori aktif.

Kemampuan penalaran matematis siswa juga dapat dilihat dari distribusi nilai post-test siswa dengan menggunakan pendekatan pembelajaran matematika realistik dan pendekatan saintifik. Adapun distribusi kemampuan penalaran matematis siswa tersebut dapat dilihat pada tabel berikut. 
Tabel 4.6

Distribusi Nilai Post-Test Kemampuan Penalaran Matematis Siswa yang diajar dengan Pendekatan Pembelajaran Matematika Realistik dan Pendekatan Saintifik

\begin{tabular}{cccccc}
\hline \multirow{2}{*}{ Rentang Nilai } & Kategori & $\begin{array}{c}\text { Pendekatan PMR } \\
\text { Frekuensi }\end{array}$ & $\begin{array}{c}\text { Pendekatan Saintifik } \\
(\boldsymbol{\%})\end{array}$ & Frekuensi & $\begin{array}{c}\text { Persentase } \\
(\%)\end{array}$ \\
\hline $80<X \leq 100$ & Sangat Baik & 11 & 64,71 & 5 & 29,41 \\
$60<X \leq 80$ & Baik & 5 & 29,41 & 7 & 41,18 \\
$40<X \leq 60$ & Cukup & 1 & 5,88 & 5 & 29,41 \\
$20<X \leq 40$ & Kurang & 0 & 0 & 0 & 0 \\
$0<X \leq 20$ & Sangat Kurang & 0 & 0 & 0 & 0 \\
\hline \multicolumn{2}{c}{ Jumlah } & 17 & 100 & 17 & 100 \\
\hline
\end{tabular}

Pembelajaran juga dikatakan efektif jika rata-rata skor siswa dinilai beradapada kategori "baik" atau "sangat baik". Skor siswa yang tidak memenuhi kriteria keefektifan akan dijadikan bahan pertimbangan untuk merevisi perangkat pembelajaran selanjutnya.

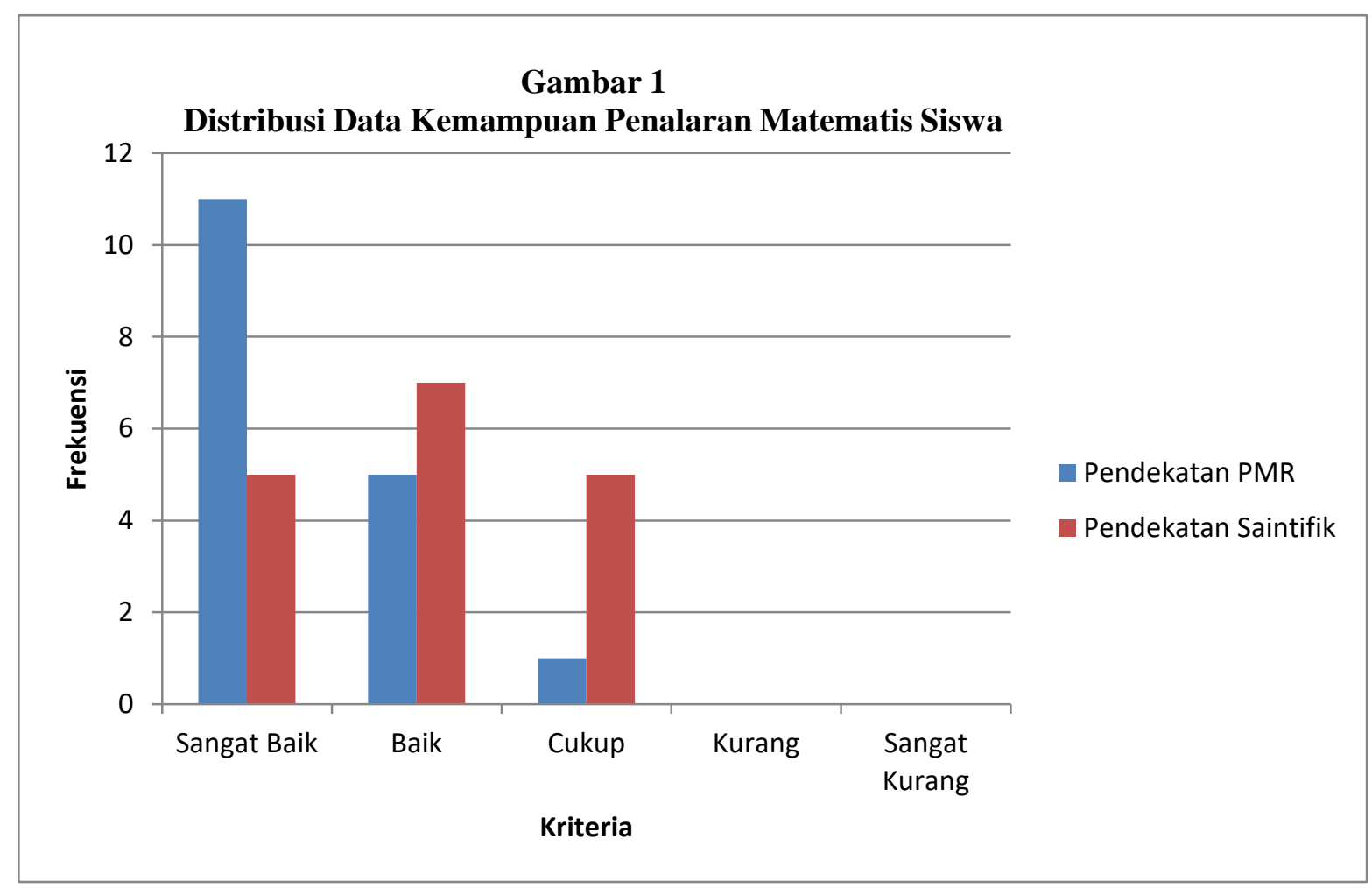

Gambar 1 menunjukkan bahwa kemampuan penalaran matematis siswa yang diajar dengan pendekatan pembelajaran matematika realistik pada kelas eksperimen lebih baik daripada kemampuan siswa yang diajar dengan pendekatan saintifik dikelas kontrol pada materi bangun ruang sisi datar gabungan.

Distribusi nilai post-test merupakan distribusi nilai yang diperoleh setelah adanya perlakuan berupa pembelajaran menggunakan pendekatan pembelajaran matematika realistik. Hasil analisis deskriptif nilai post-test siswa menggunakan aplikasi SPSS 26 
Tabel 4

Deskripsi Statistik Data pada Kelas Eksperimen dan Kelas Kontrol

\begin{tabular}{ccc}
\hline Kelas & Statistik & Nilai \\
\hline \multirow{2}{*}{ Eksperimen } & Mean & 82,6335 \\
& Standar Deviasi & 14,08173 \\
& Median & 90,4800 \\
\multirow{2}{*}{ Kontrol } & Mean & 71,1488 \\
& Standar Deviasi & 16,45099 \\
& Median & 76,1900
\end{tabular}

\begin{abstract}
diperoleh bahwa Hasil analisis deskriptif sebagaimana disajikan pada tabel diatas terlihat bahwa nilai rata-rata kemampuan penalaran matematis siswa yang diajar dengan menggunakan pendekatan pembelajaran matematika realistik sebesar 82,6335, sedangkan rata-rata kemampuan penalaran matematis siswa yang diajar dengan menggunakan pendekatan saintifik sebesar 71,1488. Selisih rata-rata kemampuan penalaran matematis kedua kelas tersebut adalah 11,4847. Hal ini menunjukkan selisih yang cukup besar sehingga rata-rata kemampuan matematis siswa yang diajar dengan menggunakan pendektan pembelajaran matematika realistik lebih dari rata-rata kemampuan penalaran matematis siswa yang diajar dengan menggunakan pendekatan saintifik.
\end{abstract}

Standar deviasi sebesar 14,08173 untuk siswa yang diajar dengan pendekatan pembelajaran matematika realistik dan 16,45099 untuk siswa yang diajar dengan pendekatan saintifik. Hal ini menunjukkan bahwa kemampuan penalaran matematis siswa pada kelas kontrol lebih beragam artinya bahwa kemampuan penalaran matematis siswa menyebar jauh dari rata-rata. Dengan kata lain pada kelas kontrol antara siswa yang memiliki kemampuan yang baik dan siswa yang memiliki kemampuan yang kurang baik memiliki selisih yang lebih besar dibandingkan dengan kelas eksperimen.

Median pada kelas eksperimen sebesar 90,4800 sedangkan pada kelas kontrol sebesar 76,1900 . Adapun nilai minimum pada kelas eksperimen sebesar 57,14 dan nilai maksimumnya sebesar 100,00 , sedangkan nilai minimum pada kelas kontrol sebesar 42,86 dan nilai maksimumnya sebesar 95,24. Varians kemampuan penalaran matematis siswa yang diajar dengan pendekatan pembelajaran matematika realistik sebesar 198,295 sedangkan varians kemampuan penalaran matematis siswa yang diajar dengan pendekatan saintifik sebesar 270,635. Skeweness (kemiringan) pada kelas eksperimen sebesar $-0,589$ sedangkan pada kelas kontrol sebesar -0,078. Hal ini menunjukkan bahwa pada kelas eksperimen dan kelas kontrol lebih banyak siswa yang mempunyai kemampuan diatas rata-rata.

Analisis inferensial yang digunakan dalam penelitian ini adalah uji hipotesis dengan uji-t. Melalui analisis inferensial kita dapat mengetahui apakah hipotesis dalam penelitian ini diterima atau ditolak. Dalam analisis ini, terdapat beberapa analisis yang menjadi prasyarat untuk melakukan uji hipotesis yaitu uji normalitas data. Uji normalitas data dimaksudkan untuk mengetahui apakah data yang diperoleh berasal dari populasi yang berdistribusi normal atau tudak. Uji normalitas data dalam penelitian ini menggunakan statistik Shapiro Wilk dengan bantuan aplikasi SPSS. Hal ini diperlukan dalam rangka penentuan jenis metode analisis data yang digunakan. Adapun pasangan hipotesis data yang digunakan adalah sebagai berikut.

$\mathrm{H}_{0}$ : sampel berasal dari data yang berdistribusi normal

$\mathrm{H}_{1}$ : sampel berasal dari data yang tidak berdistribusi normal

Dengan kriteria:

Jika nilai Asymp. Sig (2-Tailed $)>\alpha=0,05$ maka $\mathrm{H}_{0}$ diterima

Jika nilai Asymp. Sig (2-Tailed) $<\alpha=0,05$ maka $\mathrm{H}_{0}$ ditolak 
Hasil analisis uji normalitas data post-test kemampuan penalaran matematis siswa dapat dilihat pada tabel berikut.

Tabel 5

Hasil Uji Normalitas Data

\begin{tabular}{cccc}
\hline \multirow{2}{*}{ Kelas } & \multicolumn{3}{c}{ Shapiro-Wilk } \\
& Statistic & df & Sig. \\
\hline Eksperimen & 0,894 & 17 & 0,054 \\
Kontrol & 0,951 & 17 & 0,464 \\
\hline
\end{tabular}

Berdasarkan hasil analisis uji normalitas data post-test tabel dapat dilihat bahwa nilai Asymp. Sig (2-Tailed) untuk kelas eksperimen adalah $0,054>\alpha=0,05$ sehingga $\mathrm{H}_{0}$ diterima maka dapat disimpulkan bahwa kemampuan penalaran matematis siswa kelas eksperimen berasal dari populasi yang berdistribusi normal. Sedangkan Asymp. Sig (2-Tailed) untuk kelas kontrol adalah $0,054>\alpha=0,05$ sehingga $\mathrm{H}_{0}$ diterima maka dapat disimpulkan bahwa kemampuan penalaran matematis siswa kelas kontrol berasal dari populasi yang berdistribusi normal.

Data yang diperoleh berdistribusi normal dan homogen, maka untuk menguji kesamaan dua rata-rata antara kemampuan penalaran matematis siswa yang diajar dengan pendekatan pembelajaran matematis dan kemampuan penalaran matematis siswa yang diajar dengan pendekatan saintifik digunakan uji $\mathrm{t}$ (independent sample t-test). Rumusan hipotesis statistik yang akan diuji adalah $\mathrm{H}_{0}: \mu_{1}=\mu_{2}$ lawan $\mathrm{H}_{1}: \mu_{1}>\mu_{2}$

Pengujian hipotesis menggunakan uji-t (independent sample t-test) dilakukan dengan menggunakan bantuan aplikasi SPSS. Berdasarkan uji hipotesis terlihat bahwa nilai sig. $(2$-Tailed $)=0,036<\alpha=0,05$ sehingga $\mathrm{H}_{0}$ ditolak. Hal ini berarti bahwa rata-rata kemampuan penalaran matematis siswa yang diajar dengan pendekatan pembelajaran matematika realistik lebih dari rata-rata kemampuan penalaran matematis siswa yang diajar dengan pendekatan saintifik. Jadi, pendekatan pembelajaran matematika realistik lebih efektif dibandingkan dengan pendekatan pembelajaran saintifik terhadap kemampuan penalaran matematis siswa.

\section{Pembahasan}

Salah satu penyebab sulitnya mengembangkan kemampuan penalaran matematis siswa adalah guru menyajikan matematika sebagai produk jadi, siap pakai, dan diajarkan secara mekanistik dalam hal ini guru mendiktekan rumus dan prosedur matematika ke siswa sehingga kebanyakan siswa hanya menggunakan rumus dan prosedur tanpa memahaminya. Siswa juga tidak dibiasakan untuk mengenal konsep matematika berdasarkan masalah-masalah dalam dunia nyata sehingga siswa menganggap pelajaran matematika tidak bermakna dalam kehidupan sehari-harinya. Oleh karena itu, guru perlu memilih pendekatan yang efektif terhadap kemampuan penalaran matematis siswa.

Penelitian yang dilakukan oleh Ari Dhamayanti dan Ariyadi Wijaya dengan judul "Efektivitas Pendidikan Matematika Realistik Indonesia (PMRI) Ditinjau dari Kemampuan Penalaran dan Kemampuan Pemecahan Masalah Siswa SMP" yang menyimpulkan bahwa pembelajaran dengan pendekatan PMRI efektif ditinjau dari kemampuan penalaran siswa. Adapun penelitian yang dilakukan oleh Yuni Marlina dan Awaluddin pada tahun 2014 dengan Judul "Efektifitas Pendekatan Pembelajaran Matematika Realistik Terhadap Kemampuan Penalaran Matematis Siswa Kelas VII SMPN 10 Kendari" menyimpulkan bahwa pembelajaran menggunakan Pembelajaran Matematika Realistik (PMR) secara signifikan lebih efektif terhadap kemampuan penalaran matematis siswa pada materi pecahan, kelas VII semester ganjil SMP Negeri 10 Kendari tahun ajaran 2013/2014. Penelitian yang dilakukan oleh Muhammad Bahrul 'Ulum dengan judul Perbedaan Hasil Belajar Matematika Siswa dengan Menggunakan Pendekatan Saintifik dan PMR pada Materi Peluang Kelas VIII MTs 
Sunan Kalijogo Picisan Sendan Tahun Ajaran 2017/2018" menyimpulkan bahwa pembelajaran dengan pendekatan PMR lebih efektif dibandingkan dengan pendekatan saintifik terhadap hasil belajar matematika siswa pada Materi Peluang Kelas VIII MTs Sunan Kalijogo Picisan Sendan.

Berikut ini akan diuraikan pembahasan terhadap beberapa temuan sehubungan dengan kemampuan penalaran matematis siswa.Data kemampuan penalaran matematis siswa diperoleh melalui post-test kemampuan penalaran matematis siswa yang diajar dengan pendekatan pembelajaran matematika realistik sebagai kelas eksperimen dan kemampuan penalaran matematis siswa yang diajar dengan pendekatan saintifik sebagai kelas kontrol. Tes diperoleh dilakukan setelah pelakuan pada materi bangun ruang sisi datar.

Berdasarkan analisis deskriptif dari data, nilai rata-rata siswa yang diajar dengan pendekatan pembelajaran matematika realistik sebesar 82,6335 sedangkan nilai rata-rata siswa yang diajar dengan pendekatan saintifik sebesar 71,1488 . Selisih rata-rata kemampuan penalaran matematis kedua kelas tersebut adalah 11,4847. Hal ini menunjukkan selisih yang cukup besar sehingga rata-rata kemampuan matematis siswa yang diajar dengan menggunakan pendektan pembelajaran matematika realistik lebih tinggi dari rata-rata kemampuan penalaran matematis siswa yang diajar dengan menggunakan pendekatan saintifik.

Standar deviasi sebesar 14,08173 untuk siswa yang diajar dengan pendekatan pembelajaran matematika realistik dan 16,45099 untuk siswa yang diajar dengan pendekatan saintifik. Hal ini menunjukkan bahwa kemampuan penalaran matematis siswa pada kelas kontrol lebih beragam artinya bahwa kemampuan penalaran matematis siswa menyebar jauh dari rata-rata. Dengan kata lain pada kelas kontrol antara siswa yang memiliki kemampuan yang baik dan siswa yang memiliki kemampuan yang kurang baik memiliki selisih yang lebih besar dibandingkan dengan kelas eksperimen.

Median pada kelas eksperimen sebesar 90,4800 sedangkan pada kelas kontrol sebesar 76,1900 . Adapun nilai minimum pada kelas eksperimen sebesar 57,14 dan nilai maksimumnya sebesar 100,00 , sedangkan nilai minimum pada kelas kontrol sebesar 42,86 dan nilai maksimumnya sebesar 95,24. Varians kemampuan penalaran matematis siswa yang diajar dengan pendekatan pembelajaran matematika realistik sebesar 198,295 sedangkan varians kemampuan penalaran matematis siswa yang diajar dengan pendekatan saintifik sebesar 270,635. Skeweness (kemiringan) pada kelas eksperimen sebesar -0,589 sedangkan pada kelas kontrol sebesar -0,078. Hal ini menunjukkan bahwa pada kelas eksperimen dan kelas kontrol lebih banyak siswa yang mempunyai kemampuan diatas reta-rata.

Pengujian hipotesis dalam penelitian ini menggunakan uji t (Independent Sample T-Test). Berdasarkan uji hipotesis diperoleh nilai sig. (2Tailed) $=0,036<\alpha=0,05$ sehingga $\mathrm{H}_{0}$ ditolak Hal ini berarti bahwa rata-rata kemampuan penalaran matematis siswa yang diajar dengan pendekatan pembelajaran matematika realistik lebih dari rata-rata kemampuan penalaran matematis siswa yang diajar dengan pendekatan saintifik. Jadi, dapat disimpulkan bahwa pendekatan pembelajaran matematika realistik lebih efektif dibandingkan dengan pendekatan pembelajaran saintifik terhadap kemampuan penalaran matematis siswa.

\section{Simpulan dan Saran}

\section{Simpulan}

Berdasarkanhasil penelitian dan pembahasan maka dapat ditarik kesimpulan sebagai berikut:

1. Aktivitas siswa yang diajar dengan pendekatan PMR dan pendekatan saintifik efektif dengan rata-rata skor dari setiap pertemuan dinilai berada pada kategori "aktif" atau "sangat aktif".

2. Kemampuan guru dalam mengelola pembelajaran efektif dengan rata-rata skor dari setiap pertemuan dinilai berada pada kategori "baik" dan "sangat baik".

3. Respon siswa positif karena $80 \%$ atau lebih persentase respon siswa dalam kategori senang, baru, berminat, jelas dan tertarik untuk setiap aspek yang direspon.

4. Kemampuan penalaran matematis siswa kelas VIII SMP Negeri 10 Kendari yang diajar dengan menggunakan pendekatan PMR diperoleh nilai rata-rata sebesar 82,6335; standar deviasi sebesar 14,08173; dan varians sebesar 198,295.

5. Kemampuan penalaran matematis siswa kelas VIII SMP Negeri 10 Kendari yang 
diajar dengan menggunakan pendekatan saintifik diperoleh nilai rata-rata sebesar 71,1488; standar deviasi sebesar 16,45099; dan varians sebesar 270,635.

6. Pendekatan PMR efektif terhadap kemampuan penalaran matematis siswa kelas VIII SMP Negeri 10 Kendari

7. Berdasarkan uji hipotesis diperoleh bahwa pendekatan pembelajaran matematika realistik (PMR) secara signifikan lebih efektif dibandingkan dengan pendekatan pembelajaran saintifik terhadap kemampuan penalaran matematis siswa kelas VIII SMP Negeri 10 Kendari.

\section{Saran}

Berdasarkan uraian pada hasil penelitian, pembahasan dan kesimpulan tersebut, peneliti memberikan beberapa saran sebagai berikut:

1. Pendekatan pembelajaran matematika realistik (PMR) dapat dijadikan sebagai salah satu alternatif pendekatan pembelajaran yang efektif terhadap kemampuan penalaran matematis siswa.

2. Guru harus memiliki kemampuan mengajar secara profesional sehingga dapat menerapkan pendekatan pembelajaran matematika realistik secara maksimal.

3. Masalah-masalah yang dikemas pada pembelajaran matematika dengan pendekatan pembelajaran matematika realistik harus masalah-masalah kongkret dan dapat dibayangkan oleh siswa sehingga guru harus benar-benar kreatif dalam menemukan masalah-masalah tersebut dalam kehidupan nyata yang sesuai dengan materi yang akan diajarkan dikelas.

\section{Daftar Pustaka}

Ahiri, Jafar \& Anwar Hafid. (2011). Evaluasi Pembelajaran dalam Konteks KTSP. Bandung: Humaniora

Ainun Handayani, Sri. (2018). Efektivitas Pembelajaran Matematika Melalui Pendekatan Pendidikan Matematika Realistik Indonesia (PMRI) Terhadap Hasil Belajar Siswa Kelas VII SMP Negeri 5 Kendari. (Skripsi) Fakultas Keguruan dan Ilmu Pendidikan Universitas Halu Oleo
Depdikbud. (2013). Himpunan Peraturan Republik Indonesia Bidang Pendidikan. Jakarta: Depdikbud

Dhamayanti, Ari \& Ariyadi Wijaya. (2012). Efektivitas Pendekatan Pendidikan Matematika Realistic Indonesia (PMRI) ditinjau dari Kemampuan Penalaran dan Kemampuan Pemecahan Masalah Siswa SMP.JPPM, 10(2), Hal 110

Hadi, S. (2017). Pendidikan Matematika Realistik: Teori, Pengembangan dan Implementasinya. Jakarta:. Raja grafindo Persada.

Hidayat, Wahyu \& Hamidah. (2014). Retensi Daya Matematik Siswa SMA Melalui Pembelajaran MEAS. JPPM, 7 (1), Hal 18.

Ito, M. (2014). Upaya Meningkatkan Aktivitas dan Hasil Belajar Siswa pada Mata Pelajaran Matematika Bahasan Kesabangunan Segitiga melalui Pendekatan Realistic Mathematics Education. JPPM. 7(1), Hal 74

Leksono, J. W. (2015). Pendekatan Saintifik pada Kurikulum 2013 untuk Meningkatkan Keterampilan Berpikir Kritis Siswa. proceedingfptk, 4(37).

Marlina, Yuni \& Awaluddin. (2014). Efektivitas Pendekatan Pembelajaran Matematika Realistik Tehadap Kemampuan Penalaran Matematis Siswa Kelas VII SMP Negeri 10 Kendari. JPPM, 2 (2), Hal 207-208

Megantara, M. (2017). Efektivitas Realistik Mathematics Education (RME) Ditinjau dari Pemahaman Konsep Matematis Siswa. (Skripsi) Fakultas Keguruan dan Ilmu Pendidikan Universitas Lampung.

Mente, H dan Jazuli, L.O.A. (2014). Pengaruh Model Pembelajaran Problem Based Learning Terhadap Hasil Belajar Matematika Siswa Kelas X Sma Negeri 9 Kendari. Jurnal Penelitian Pendidikan Matematika. 2(2), 53.

Muhammad, M., \& Nurdyansyah, N. (2015). Pendekatan pembelajaran saintifik. Sidoarjo: Nizamia Learning Center.

National Council of Teacher of Mathematics. (2000). Principle and Standard for 
School of Mathematics. USA: National Council of Teacher of Mathematics.

Nuruddin, M., \& Suwito, D. (2019) Pengembangan Modul Teknologi Mekanik Untuk Meningkatkan Hasil Belajar Dan Keterlaksanaan Pembelajaran Kelas X Jurusan Teknik Pemesinan Smk Pgri 1 Gresik. Jurnal Pendidikan Teknik Mesin, 8(3).

Octriana, Iga dkk. (2019). Penalaran Matematis Siswa Dalam Pembelajaran Pola Bilangan Menggunakan Pmri Dan Lslc. Jurnal Pendidikan Matematika, 13(2), Hal 131

Permana, Y. \& Utari S. (2007). Mengembangkan Kemampuan Penalaran dan Koneksi Matematik Siswa SMA Melalui Pembelajaran Berbasis Masalah. UPI, I (2)

Puspa, Gheovani. (2014). Efektivitas Pembelajaran Matematika dengan Pendekatan Model-Elicting Activities (MEAs) pada Materi Persamaan dan Pertidaksamaan Linear Satu Variabel dikelas VII-A SMP Negeri 1 Lamongan. MATHEdunesa, 3 (2).

Saepudin,Aep dkk. (2009). Gemar Belajar Matematika. Jakarta: Pusat Perbukuan Departemen Pendidikan Nasional

Saleh. (2008). Pengembangan dengan Pendekatan PMR Pada Topik Persegi Panjang dan Persegi di Kelas VII SMP Negeri 9 Kendari”. MIPMIPA, 7 (2), Hal 103

Saleh. (2017).Pembelajaran Matematika Realistik untuk Topik Persegi Panjang dan Persegi dikelas VII SMP Negeri 9 Kendari. (Tesis) Universitas Negeri Surabaya

Sembiring. (2010). Pendidikan Matematika Realistik Indonesia (PMRI): Perkembangan dan Tantangannya. JME, 1 (1), Hal 12

Septiana, F., Mujib, M., \& Negara, H. S. (2018). Penerapan Pendekatan Pendidikan Matematika Realistik Indonesia (PMRI) ditinjau dari Multiple Intelligences. Desimal: Jurnal Matematika, 1(1), 2328.
Sermatan, Elfiyanti, et al. (2018). Peningkatan Kemampuan Penalaran Aljabar Siswa melalui Problem Based Learning dan Konvensional pada Siswa Madrasah Tsanawiah. JPM, 9 (1)

Sinambela, P.N. (2008). Faktor-faktor Penentu Keefektifan Pembelajaran dalam Model Pebelajaran Berdasarkan Masalah (Problem Based Instruction). Generasi Kampus, 1(2)

Sinambela, P. N. (2017). Kurikulum 2013 dan implementasinya dalam pembelajaran Generasi Kampus, 6(2).

Sudjana. (2000). Metoda Statistika Edisi Ke-6. Bandung: Tarsito

Sugiyono. (2008). Metode Penelitian Pendidikan (Pendekatan Kuantitatif, Kualitatif dan $R \quad \& \quad D)$. Bandung: Alfabeta

Sugiyono. (2018). Metode Penelitian Kuantitatif. Bandung: Alfabeta

Susilowati, E. (2018). Peningkatan Aktivitas dan Hasil Belajar Matematika Siswa SD melalui Model Realistic Mathematics Education (RME) pada Siswa Kelas IV Semester 1 di SD 4 Kradenan Kecamatan Kradenan Kabupaten Grobogan Tahun Pelajaran 2017/2018. Jurnal PINUS,4 (1)

Teguh, H. (2016). Efektivitas Pendekatan Pembelajaran Matematika Realistik Terhadap Kemampuan Pemecahan Masalah Matematis Siswa Kelas VIII SMPN 8 Kendari. JPM, 4(2)

Tripuasarina, D. (2015). Efektivitas Pembelajaran Matematika Menggunakan Model Student Team Achievement Division dengan Program SPSS pada Materi Statistika Kelas XI SMA Muhammadiyah 1 Gresik. (Doctoral dissertation), Universitas Muhammadiyah Gresik

Wibowo, A. (2017). Pengaruh Pendekatan Pembelajaran Matematika Realistik Dan Saintifik Terhadap Prestasi Belajar, Kemampuan Penalaran Matematis Dan Minat Belajar. Jurnal Riset Pendidikan Matematika, 4(1), 1-10. 
Wulandari, E. (2011). Meningkatkan Kemampuan Penalaran Matematis melalui Problem Posing. Diakses pada tanggal 1 oktober 2019 dari postingan http://eprints.uny.ac.id/1709/1/EnikaWu landari.pdf 